\title{
Simulation study and economic analysis of large-scale solar heating plants in Spain
}

\author{
Miguel A. Lozano ${ }^{*}$, Antonio Anastasia ${ }^{2}$, Fernando Palacín ${ }^{3}$, and Luis M. Serra ${ }^{{ }^{*}}$ \\ ${ }^{1}$ GITSE-I3A, Universidad de Zaragoza, Maria de Luna 3, 50018 Zaragoza, Spain \\ 2 Department of Energetics, Politecnico dei Torino, Corso Duca degli Abruzzi 24, 10129 Torino, Italy \\ ${ }^{3}$ National Renewable Energy Centre (CENER), Ciudad de la Innovación 7, 31192 Sarriguren (Navarra), Spain \\ * Corresponding Author, serra@unizar.es
}

\begin{abstract}
When the focus of solar thermal systems remains solely for domestic hot water (DHW) production, as it is the case of Spanish regulation, then the contribution of solar thermal energy to raise the share of renewable energy in the EU's energy mix to $20 \%$ by 2020 will be very limited. In this paper the experience gained in Europe with Central Solar Heating Plants combined with Seasonal Storage (CSHPSS) systems has been transferred to the Spanish situation, in order to establish the conditions and criteria for installing these systems in the mid-term. A simulation study on solar assisted district heating systems with high solar fractions was carried out taking into consideration the meteorological conditions and heat demands in the residential sector for different cities in Spain and various values of heat loads from 500 to $5000 \mathrm{MWh}$ /year. Results have shown that: i) design criteria for Spain are different, less solar collector area is necessary with a greater ratio between storage volume and collector area, ii) specific total heat cost mainly depend on the size of the system; and iii) specific solar heat cost and solar fraction significantly vary with the heat demand and solar radiation corresponding to the geographical location of the system.
\end{abstract}

\section{Introduction}

The European Union and its Member States have committed themselves to achieving a $20 \%$ share of renewable energy by 2020. If the focus remains solely on solar thermal systems for domestic hot water (DHW) preparation, as in Spain, then the solar contribution will be very limited. CSHPSS systems coupling the offer of thermal energy in periods of high solar radiation (summer) with high thermal energy demand for heating (winter) enable high solar fractions of $50 \%$ and more, obtaining energy independence, energy saving and reduction of pollutant emissions.

With the new legislation on buildings construction [1], the Spanish Government has started a lukewarm promotion of the installation of thermal solar systems in buildings. Specifically, the new Spanish legislation on buildings construction imposes the coverage with thermal solar energy of the $30 \%-70 \%$ (depending on the climatic area) of energy demand corresponding to the domestic hot water. In other countries an important experience on thermal solar energy has already been gained and several high scale Central Solar Heating Plants (CSHP) have been designed to cover the thermal energy demand of urban districts and even small cities [2-3]. Some of these plants have proven the appropriate operation of seasonal thermal energy storage and have reached high solar fractions [4-5]. Most CSHPSS demonstration plants in Europe have been built in Germany, Denmark and Sweden. 
The experience gained in these countries and the better conditions of solar radiation in Spain suggest the feasibility of installing CSHPSS in those Spanish areas in which there is a significant demand of thermal energy for heating in winter.

In this paper the experience gained in Europe about CSHPSS systems has been transferred to the Spanish situation, in order to establish the conditions and criteria for installing these systems in the mid-term. A CSHPSS system is proposed that will be used as a reference case for the selection and sizing of the required pieces of equipment as well as for the evaluation of its economic feasibility. The dynamic behaviour of the system has been analyzed using the TRNSYS software [6]. It is presented a technical and economic evaluation of a CSHPSS plant that could be able of covering about $70 \%$ of the thermal energy demand for DHW and heating of residential areas between 100 to 1000 dwellings in Zaragoza. Furthermore cities located in different climatic areas of Spain, requiring heating in winter and with significant variety of solar radiation have been considered.

\section{System description}

The proposed system that provides DHW and heating to a group of buildings is depicted in Figure 1. The solar circuit is separated by heat exchangers from the storage circuits since a water-glycol mixture is used to protect the collector field against frost damage. The energy harnessed by the solar collectors is transferred either to the seasonal thermal energy storage or to the DHW storage (preferably to this one). The seasonal heat storage is a cylindrical water tank made of concrete. A load heat exchanger which separates the seasonal storage circuit from the district heating net is installed to preheat the return flow of the buildings. An independent DHW storage, which is smaller than the seasonal thermal energy storage, provides the required temperature of the water in a few hours and allows, as it is explained below, to cover a high fraction of the DHW demand with solar energy. The dynamics of loading and unloading of the seasonal thermal energy storage is significantly slower, because it is oriented to cover partially the heating demand in winter using the thermal energy stored during the summer period. The auxiliary boilers (BH and BDHW) will support and guarantee the coverage of the thermal demands when the temperature of the water in thermal energy storages is insufficient.

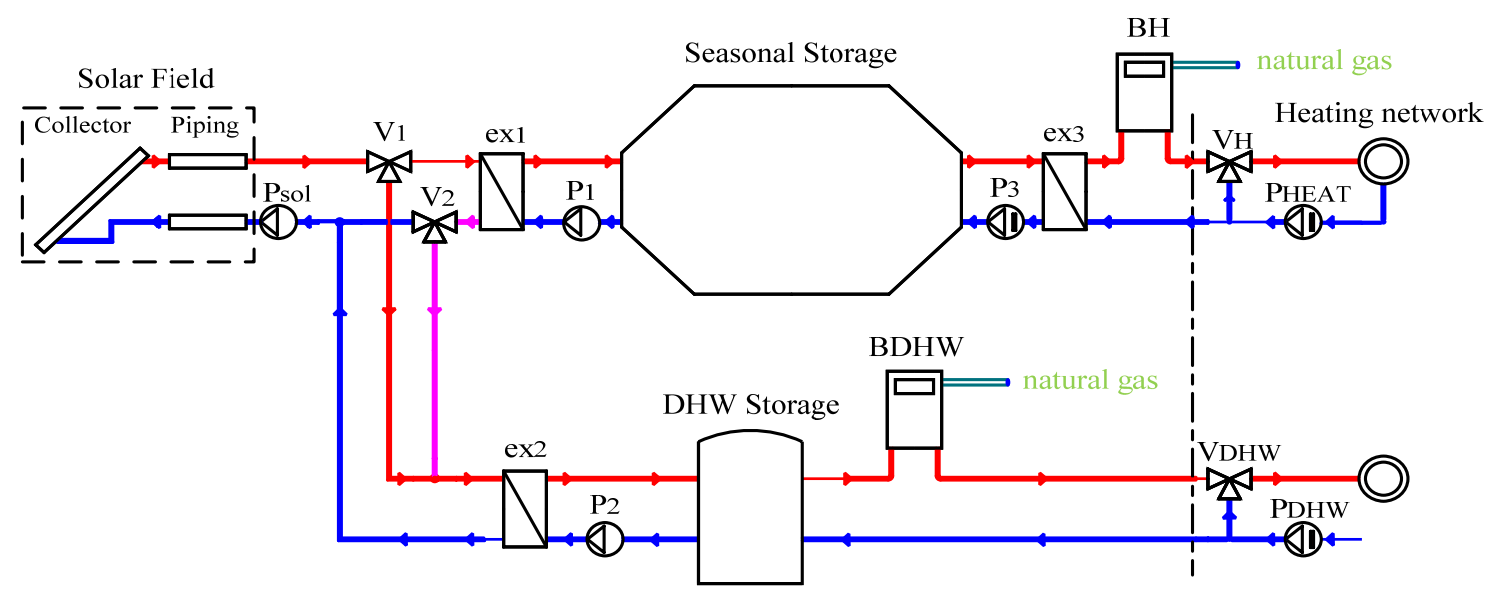

Fig. 1. Diagram of the analyzed Central Solar Heating Plant combined with Seasonal Storage 


\section{Base case}

The CSHPSS base plant is designed to serve 500 dwellings in a residential area located in Zaragoza (Spain). The thermal energy demand for DHW and heating is expressed considering 12 representative days (one for each month of the year) divided each in 24 periods of 1 hour [7]. The annual thermal energy demand is GD = 2,905 MWh/year, being DD = 507.5 MWh/year for domestic hot water and $\mathrm{HD}=2,397.5 \mathrm{MWh} /$ year for heating.

DHW is produced at $60^{\circ} \mathrm{C}$. The proposed CSHPSS plant produces water at $50^{\circ} \mathrm{C}$ for a low temperature heating network, which is favourable for maximizing the efficiency in thermal solar plants. A typical low temperature heating system is for instance the radiant floor heating system.

The selection of pieces of equipment has been made for solar collectors, thermal energy storages, auxiliary boilers, heat exchangers and pumps, based either on the information appearing in catalogs (boilers, heat exchangers and pumps) or on the information published in the scientific literature (collector field and seasonal thermal energy storage).

Flat plate collectors are used to collect solar radiation. These collectors have surfaces higher than 10 $\mathrm{m}^{2}$ and they can be installed either on the roof of a building and/or on the ground. The proposed surface to be installed in the base case is $\mathrm{A}=2,760 \mathrm{~m}^{2}$ on the ground, corresponding to a design ratio of $\mathrm{A} / \mathrm{GD}=0.95 \mathrm{~m}^{2} /(\mathrm{MWh} /$ year $)$.

The sizing of the DHW storage was based on the medium daily demand. The volume of the selected DHW was $47 \mathrm{~m}^{3}$, sufficient for two days. The volume of the seasonal thermal energy storage, required for reaching a maximum top temperature of $100^{\circ} \mathrm{C}$ before the beginning of the heating period, was estimated about $\mathrm{V}=15,180 \mathrm{~m}^{3}\left(\mathrm{~V} / \mathrm{A}=5.5 \mathrm{~m}^{3} / \mathrm{m}^{2}\right)$. Due to the big size, this thermal energy storage should be built in the place where it will be located.

Auxiliary boilers with a thermal power of $208 \mathrm{~kW}$ for the production of domestic hot water and 1,800 $\mathrm{kW}$ for heating are able of covering all the thermal demand (100\%) without usage of the solar thermal system. The heat exchangers were designed establishing an overall UA coefficient that could guarantee a heat exchanger effectiveness of 0.95 , even in the worst operation conditions. The sizing of the circulating pumps was established considering the maximum volume of flow and the pressure loss in the different pieces of equipment connected in series to the pump.

\subsection{TRNSYS model}

TRNSYS is a software tool providing a complete environment for the dynamic simulation of energy systems. In Table 1 are shown the different TRNSYS types that have been used for the simulation of the components, as well as the most relevant technical parameters of the designed system.

Hourly thermal demands, both for domestic hot water and for heating, are registered in a text file and are provided to the model. All the demand values were obtained from direct measurements taken in several dwellings located in the residential area of Parque Goya, located in the city of Zaragoza. Climatic data (solar radiation and ambient temperature) for the city of Zaragoza (Height: $247 \mathrm{~m}$; Latitude: $41.39^{\circ} \mathrm{N}$; Longitude: $1.00^{\circ} \mathrm{W}$ ) were obtained from EnergyPlus [8]. Cold temperature from the domestic water supply network is taken from Standard UNE 94002 [9]. 
Table 1. TRNSYS model of the different plant components

\begin{tabular}{|c|c|c|c|c|c|c|c|c|}
\hline \multicolumn{2}{|c|}{ Component } & Type & Parameter & Value & Component & Type & Parameter & Value \\
\hline \multirow{5}{*}{$\begin{array}{r}\text { Solar } \\
\text { field } \\
\text { (sf) }\end{array}$} & \multirow{3}{*}{ Collectors } & \multirow{3}{*}{$1 \mathrm{a}$} & \multirow{3}{*}{$\begin{array}{r}\text { Collector area } \\
\text { Collector number } \\
\text { Slope } \\
\text { Azimuth } \\
\mathrm{a} 0 \\
\mathrm{a} 1 \\
\mathrm{a} 2 \\
\text { Specific flow }\end{array}$} & \multirow{3}{*}{$\begin{array}{r}13.575 \mathrm{~m}^{2} \\
204 \\
50^{\circ} \\
0^{\circ} \\
0.738 \\
.63 \mathrm{~W} /\left(\mathrm{m}^{2} \mathrm{~K}\right) \\
99 \mathrm{~W} /\left(\mathrm{m}^{2} \mathrm{~K}^{2}\right) \\
20 \mathrm{~kg} /\left(\mathrm{h} \cdot \mathrm{m}^{2}\right)\end{array}$} & $\begin{array}{r}\text { Heating Boiler } \\
(\mathrm{BH})\end{array}$ & 6 & $\begin{array}{r}\text { Nominal power } \\
\text { Efficiency } \\
\text { Service Temp }\end{array}$ & $\begin{array}{r}1800 \mathrm{~kW} \\
0.93 \\
50^{\circ} \mathrm{C}\end{array}$ \\
\hline & & & & & $\begin{array}{r}\text { DHW Boiler } \\
\text { (BD) }\end{array}$ & 6 & $\begin{array}{r}\text { Nominal power } \\
\text { Efficiency } \\
\text { Service Temp } \\
\end{array}$ & $\begin{array}{r}208 \mathrm{~kW} \\
0.96 \\
60^{\circ} \mathrm{C} \\
\end{array}$ \\
\hline & & & & & $\begin{array}{r}\text { Heat exchanger } 1 \\
\text { (ex1) }\end{array}$ & $5 b$ & $\begin{array}{r}\text { Area } \\
\text { Overall U }\end{array}$ & $\begin{array}{r}285 \mathrm{~m}^{2} \\
3942 \\
\mathrm{~W} / \mathrm{m}^{2} \cdot \mathrm{K} \\
\end{array}$ \\
\hline & \multirow{2}{*}{ Pipes } & \multirow{2}{*}{709} & \multirow{2}{*}{$\begin{array}{r}\text { Total length } \\
\text { Diameter } \\
\text { Ins. thickness } \\
\text { Ins. conductivity }\end{array}$} & \multirow{2}{*}{$\begin{array}{r}1000 \mathrm{~m} \\
0.1 \mathrm{~m} \\
0.06 \mathrm{~m} \\
0.144 \mathrm{~kJ} /(\mathrm{h} \cdot \mathrm{m} \cdot \mathrm{K})\end{array}$} & $\begin{array}{r}\text { Heat exchanger } 2 \\
(\text { ex2) }\end{array}$ & $5 b$ & $\begin{array}{r}\text { Area } \\
\text { Overall U }\end{array}$ & $\begin{array}{r}285 \mathrm{~m}^{2} \\
3942 \\
\mathrm{~W} / \mathrm{m}^{2} \cdot \mathrm{K}\end{array}$ \\
\hline & & & & & $\begin{array}{r}\text { Heat exchanger } 3 \\
\text { (ex3) }\end{array}$ & $5 b$ & $\begin{array}{r}\text { Area } \\
\text { Overall U }\end{array}$ & $\begin{array}{r}580 \mathrm{~m}^{2} \\
3931 \\
\mathrm{~W} / \mathrm{m}^{2} \cdot \mathrm{K} \\
\end{array}$ \\
\hline \multirow{2}{*}{\multicolumn{2}{|c|}{$\begin{array}{r}\text { Seasonal storage } \\
\text { (a1) }\end{array}$}} & \multirow{2}{*}{$4 c$} & \multirow{2}{*}{$\begin{array}{r}\text { Volume } \\
\text { Thermal loss } \\
\text { Height/Diameter } \\
\text { Number of nodes }\end{array}$} & \multirow{2}{*}{\begin{tabular}{r|}
$15180 \mathrm{~m}^{3}$ \\
$0.45 \mathrm{~kJ} /\left(\mathrm{h} \cdot \mathrm{m}^{2} \cdot \mathrm{K}\right)$ \\
0.6 \\
12
\end{tabular}} & $\begin{array}{r}\text { Pump - primary } \\
\text { (PS) }\end{array}$ & $3 b$ & $\begin{array}{l}\text { Nominal flow } \\
\text { Nominal power }\end{array}$ & $\begin{array}{r}54 \mathrm{~m}^{3} / \mathrm{h} \\
15 \mathrm{~kW}\end{array}$ \\
\hline & & & & & $\begin{array}{r}\text { Pump } 1 \\
\text { (P1) }\end{array}$ & $3 b$ & $\begin{array}{r}\text { Nominal flow } \\
\text { Nominal power }\end{array}$ & $\begin{array}{r}51 \mathrm{~m}^{3} / \mathrm{h} \\
1.4 \mathrm{~kW}\end{array}$ \\
\hline \multirow{2}{*}{\multicolumn{2}{|c|}{$\begin{array}{r}\text { DHW storage } \\
\text { (a2) }\end{array}$}} & \multirow{2}{*}{$4 a$} & \multirow{2}{*}{$\begin{array}{r}\text { Volume } \\
\text { Thermal loss } \\
\text { Height/Diameter } \\
\text { Number of nodes }\end{array}$} & \multirow{2}{*}{$\begin{array}{r}47 \mathrm{~m}^{3} \\
1.6 \mathrm{~kJ} /\left(\mathrm{h} \cdot \mathrm{m}^{2} \cdot \mathrm{K}\right) \\
1.5 \\
6\end{array}$} & $\begin{array}{r}\text { Pump } 2 \\
\text { (P2) }\end{array}$ & $3 b$ & $\begin{array}{r}\text { Nominal flow } \\
\text { Nominal power }\end{array}$ & $\begin{array}{r}51 \mathrm{~m}^{3} / \mathrm{h} \\
1.4 \mathrm{~kW}\end{array}$ \\
\hline & & & & & $\begin{array}{r}\text { Pump } 3 \\
\text { (P3) }\end{array}$ & 110 & $\begin{array}{r}\text { Nominal flow } \\
\text { Nominal power } \\
\end{array}$ & $\begin{array}{r}104 \mathrm{~m}^{3} / \mathrm{h} \\
3.7 \mathrm{~kW} \\
\end{array}$ \\
\hline
\end{tabular}

\subsection{Annual energy balance}

The energy balance of the whole system for a year of operation is shown in Fig. 2. The annual energy efficiency of the solar field is $48 \%$. The DHW storage has higher efficiency (98\%) than the seasonal thermal energy storage (91\%), which is reasonable.

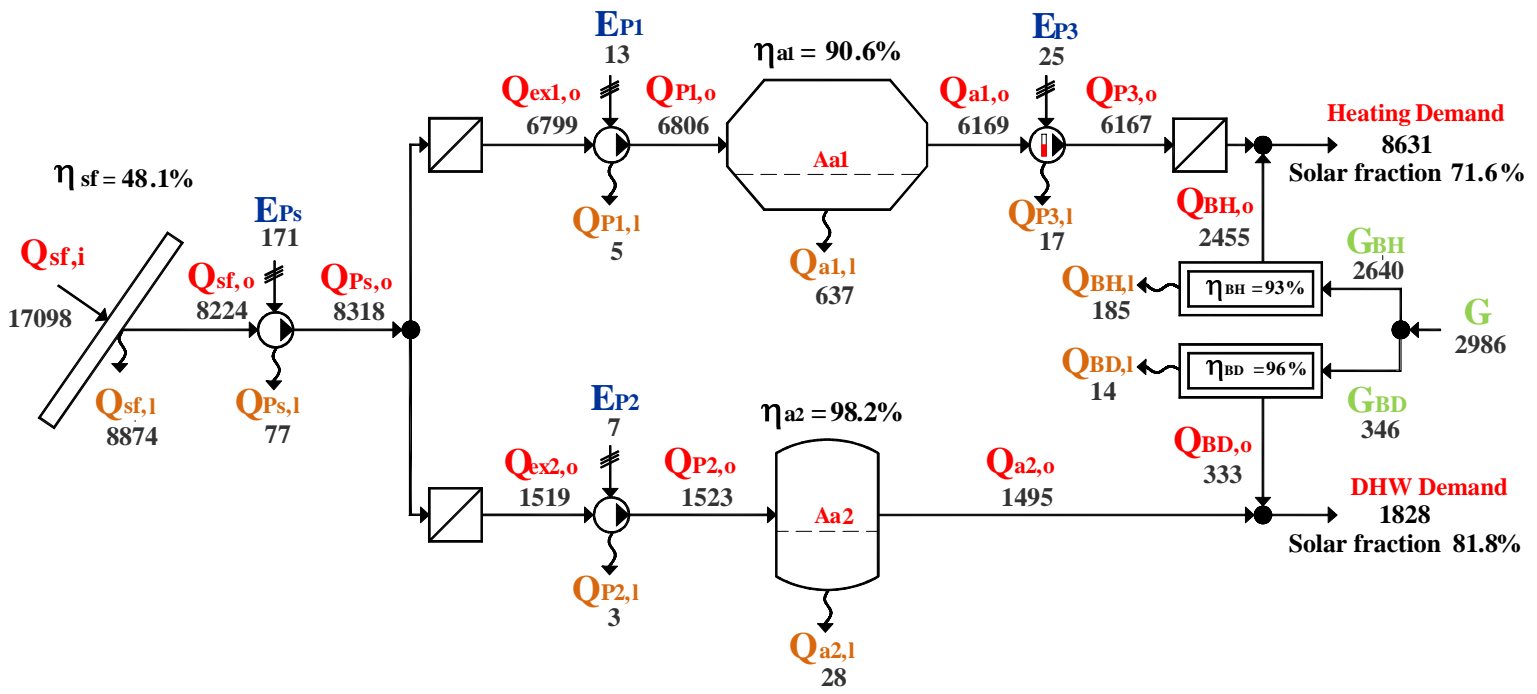

Fig. 2. Annual energy balance of the designed system (Energy flows, GJ/year) 
Table 2. Monthly operation of the analyzed system

\begin{tabular}{|c|c|c|c|c|c|c|c|c|c|c|c|}
\hline & $\begin{array}{c}\text { Qsf,i } \\
\text { (GJ) }\end{array}$ & $\begin{array}{c}\eta_{\mathrm{sf}} \\
(\%)\end{array}$ & $\begin{array}{c}\eta_{\mathrm{a} 1} \\
(\%)\end{array}$ & $\begin{array}{c}\mathbf{Q A}_{\mathrm{a} 1} \\
(\mathrm{GJ})\end{array}$ & $\begin{array}{l}\text { HD } \\
(\mathrm{GJ})\end{array}$ & $\begin{array}{c}\mathbf{S F}_{\mathrm{HD}} \\
(\%)\end{array}$ & $\begin{array}{c}\eta_{\mathrm{a} 2} \\
(\%)\end{array}$ & $\begin{array}{c}\text { DD } \\
(G J)\end{array}$ & $\begin{array}{c}\text { SF }_{\text {DD }} \\
(\%)\end{array}$ & $\begin{array}{c}\text { GB } \\
(G J)\end{array}$ & $\begin{array}{c}\mathbf{E P} \\
(\mathrm{GJ})\end{array}$ \\
\hline Jan & 974 & 52.6 & 92.8 & -360 & 2081 & 45.8 & 98.5 & 227 & 69.0 & 1287 & 18 \\
\hline Feb & 1166 & 55.5 & 95.7 & -358 & 1452 & 33.0 & 98.5 & 198 & 74.5 & 1098 & 18 \\
\hline Mar & 1529 & 57.6 & 96.4 & -313 & 997 & 65.9 & 98.5 & 203 & 79.5 & 409 & 21 \\
\hline Apr & 1489 & 56.7 & 95.9 & 37 & 333 & 95.7 & 98.3 & 167 & 92.5 & 28 & 21 \\
\hline May & 1618 & 56.4 & 95.1 & 785 & 0 & - & 98.1 & 145 & 93.5 & 10 & 20 \\
\hline Jun & 1623 & 53.4 & 93.4 & 1500 & 0 & - & 98.1 & 120 & 90.2 & 12 & 20 \\
\hline Jul & 1828 & 48.3 & 91.9 & 2256 & 0 & - & 97.0 & 73 & 97.2 & 2 & 19 \\
\hline Aug & 1872 & 41.3 & 89.4 & 2918 & 0 & - & 95.0 & 41 & 97.1 & 1 & 18 \\
\hline Sep & 1600 & 32.0 & 80.0 & 3257 & 0 & - & 97.7 & 102 & 94.4 & 6 & 14 \\
\hline Oct & 1430 & 31.8 & 72.0 & 3300 & 187 & 100 & 98.3 & 149 & 94.1 & 9 & 15 \\
\hline Nov & 1055 & 44.9 & 78.0 & 2365 & 1200 & 100 & 98.2 & 187 & 74.3 & 50 & 16 \\
\hline Dec & 914 & 50.6 & 83.5 & 256 & 2380 & 100 & 98.4 & 215 & 67.1 & 74 & 15 \\
\hline YEAR & 17098 & 48.1 & 90.6 & 256 & 8631 & 71.6 & 98.2 & 1828 & 81.8 & 2986 & 215 \\
\hline
\end{tabular}

\subsection{Dynamic behaviour of the installation}

Table 2 shows the monthly behaviour for a typical year of operation of the designed system. The highest solar radiation offer is in August. However, since March to July more thermal energy is harnessed than in August. The reason is the reduction of the energy efficiency of the solar collectors due to the temperature raise of the working fluid when the load of the seasonal thermal energy storage increases. The DHW demand is covered with solar energy with a fraction higher than $67 \%$, during all the year, and higher than $90 \%$ during the period April-October. Globally, the annual solar fraction is about $82 \%$. In the case of heating the solar fraction is higher during the beginning of the heating season. The seasonal storage is completely unloaded at the end of December because the demand has been covered with solar energy. From January to March the heating demand is still high, and all the energy received by the seasonal storage is unloaded. In April the seasonal storage starts to loading thermal energy, reaching the maximum temperature level in October. Globally, the annual solar fraction of heating is about $72 \%$. Combining both demands the annual solar fraction is about $73 \%$.

\subsection{Economic analysis}

The consumption of auxiliary energy has two parts. On one hand, the natural gas consumption in the auxiliary boilers (2,986 GJ/yr) to produce the DHW and heating demands not covered with solar energy. On the other hand, the electricity consumed by the pumps $(59,810 \mathrm{kWh} / \mathrm{yr})$. In Table 2 is shown the monthly energy consumption in detail. The annual cost of natural gas is $36,140 €$, considering a price of $12.1 € / G J$. In the case of electrical energy, the annual cost of electricity is 9,210 $€$, considering a price of $0.154 € / \mathrm{kWh}$. The total energy cost of the operation during the year is 45,350 $€$. Energy prices for Spain (2009) were taken from Eurostat [10].

The total required investment, without considering any subsidy, has been estimated in about $3,461 \cdot 10^{3}$ $€$. This estimate considers the purchase cost of the pieces of equipment of the system, as well as the installation costs and an allowance of 15\% for contingency and fees. In Table 3 are shown in detail the considered costs. Assuming the operation life-time of the system as 25 years (except 50 years for heat stores), the annual interest rate of $6 \%$, and an estimation for the annual maintenance and operation related costs about $1.5 \%$ of the investment [16], the annual non-energy cost is $283,260 €$. 
Table 3. Investment [4-5, 11-15]

\begin{tabular}{|c|c|c|c|c|c|c|}
\hline Component & Capacity & $\mathbf{a}$ & b & Cost (€) & FBM* & $\mathrm{CBM}^{\$}\left(10^{3} €\right)$ \\
\hline Solar Field sf & $2760 \mathrm{~m}^{2}$ & 740 & 0.86 & 673600 & 1.0 & 673.6 \\
\hline Seasonal storage a1 & $15180 \mathrm{~m}^{3}$ & 4660 & 0.615 & 1737200 & 1.0 & 1737.2 \\
\hline DHW storage a2 & $47.3 \mathrm{~m}^{3}$ & 3000 & 0.63 & 34050 & 2.1 & 71.5 \\
\hline Heating Boiler BH & $1800 \mathrm{~kW}$ & 155 & 0.69 & 27320 & 1.5 & 41.0 \\
\hline DHW Boiler BD & $208 \mathrm{~kW}$ & 155 & 0.69 & 6160 & 1.5 & 9.2 \\
\hline Heat Exch. ex1 & $282 \mathrm{~m}^{2}$ & 1350 & 0.70 & 70660 & 1.7 & 120.1 \\
\hline Heat Exch. ex2 & $282 \mathrm{~m}^{2}$ & 1350 & 0.70 & 70660 & 1.7 & 120.1 \\
\hline Heat Exch. ex3 & $580 \mathrm{~m}^{2}$ & 1350 & 0.70 & 116100 & 1.7 & 197.4 \\
\hline Pump Psol & $15.0 \mathrm{~kW}$ & 2200 & 0.35 & 5680 & 2.8 & 15.9 \\
\hline Pump P1 & $1.42 \mathrm{~kW}$ & 2200 & 0.35 & 2490 & 2.8 & 7.0 \\
\hline Pump P2 & $1.42 \mathrm{~kW}$ & 2200 & 0.35 & 2490 & 2.8 & 7.0 \\
\hline Pump P3 & $3.70 \mathrm{~kW}$ & 2200 & 0.35 & 3480 & 2.8 & 9.7 \\
\hline Total CBM & & & & & & 3009.6 \\
\hline Cont. and fees $15 \%$ & & & & & & 451.4 \\
\hline Total capital & & & & & & 3461.0 \\
\hline
\end{tabular}

${ }^{\&}$ Cost $=\mathrm{a} \cdot$ Capacity $^{\mathrm{b}},{ }^{*}$ Bare module installation factor FBM, ${ }^{\$}$ Bare module cost CBM $=$ Cost $\cdot$ FBM

The sum of the previous costs is equal to 328,610 €. Being 2,905 MWh the annual heat demand, the heat unit cost results $0.113 € / \mathrm{kWh}$. Boilers do not produce solar heat. The cost of the heat produced by the auxiliary boilers includes its amortization, operation and maintenance charges equal to 5,240 $€ /$ year, as well as the cost of the natural gas. The overall cost of the heat produced by boilers is 41,380 $€$ /year. Being the overall production $775 \mathrm{MWh} /$ year, the resulting unit cost of non solar heat is 0.053 $€ / \mathrm{kWh}$. The global sum of the costs due to solar heat is $287,230 €$. Being the annual production 2,130 MWh, then the resulting solar heat unit cost is $0.135 € / \mathrm{kWh}$.

\section{Comparison with German plants}

Table 4 resumes the main characteristics of similar plants installed in Germany [5] and includes the system designed for Zaragoza. The German systems belong to the same typology, include a seasonal storage system, and they use flat-plate solar collectors and hot water tank storage systems. In order to cover a given demand, several design options in terms of ratios A/GD and V/A can be used. Having Spain a higher annual radiation than Germany, some deviations on the design parameters can be observed, e.g. smaller solar collector surface and larger storage systems are required in Spain (see ratios A/GD and V/A in Table 4). The system described in this work is able to cover a solar fraction as high as $73 \%$ with a solar heat unit cost of $135 € / M W h$, significantly lower than the typical value encountered in German plants.

Table 4. Comparison of technical and economic data from several CSHPSS systems

\begin{tabular}{|l|r|r|r|r|r|r|r|}
\hline Localization & $\begin{array}{r}\text { Total } \\
\text { demand } \\
\text { GD }(\mathrm{MWh} / \mathrm{y})\end{array}$ & $\begin{array}{r}\text { Collector } \\
\text { area } \\
\left.\mathrm{Am}^{2}\right)\end{array}$ & $\begin{array}{r}\text { Seasonal } \\
\text { storage } \\
\mathrm{V}\left(\mathrm{m}^{3}\right)\end{array}$ & $\begin{array}{r}\text { Solar } \\
\text { fraction } \\
(\%)\end{array}$ & $\begin{array}{r}\text { Ratio } \\
\text { A/GD }\end{array}$ & $\begin{array}{r}\text { Ratio } \\
\text { V/A }\end{array}$ & $\begin{array}{r}\text { Solar Heat } \\
\text { cost } \\
(€ / \mathrm{kWh})\end{array}$ \\
\hline Friedrichshafen & 4106 & 5600 & 12000 & 47 & 1.36 & 2.14 & 0.159 \\
\hline Hamburg & 1610 & 3000 & 4500 & 49 & 1.86 & 1.50 & 0.257 \\
\hline Munich & 2300 & 2900 & 5700 & 47 & 1.26 & 1.97 & 0.240 \\
\hline Hanover & 694 & 1350 & 2750 & 39 & 1.95 & 2.04 & 0.414 \\
\hline Zaragoza & 2905 & 2760 & 15180 & 73 & 0.95 & 5.50 & 0.135 \\
\hline
\end{tabular}




\section{Size influence}

The behaviour of the system has been analyzed under different annual heat demands. The model, developed in TRNSYS, has been used to simulate heat loads ranging between $581 \mathrm{MWh} / \mathrm{y}$ and 5810 $\mathrm{MWh} / \mathrm{y}$ corresponding to 100 and 1000 dwellings, respectively. All the simulations have been conducted keeping constant the ratio between collector area and annual demand (A/GD $=0.95)$ as well as the ratio between the seasonal tank capacity and the collector area $(\mathrm{V} / \mathrm{A}=5.5)$. The obtained results are shown in Table 5. A clear tendency can be also observed when comparing the unit cost of solar heat: the larger the plant the lower the cost. This is due to two issues related to the sizing: firstly, economies of scale are significant; secondly, the heat losses of the seasonal storage are reduced for larger volumes. The solar fraction increases with the size of the CSHPSS system reaching a maximum limit for 500 or more dwellings.

Table 5. Technical and economic data for various CSHPSS sizes (Zaragoza; A/GD = 0.95; V/A = 5.5)

\begin{tabular}{|c|c|c|c|c|c|c|c|c|c|}
\hline $\begin{array}{c}\text { Number of } \\
\text { dwellings }\end{array}$ & $\eta_{\mathbf{S F}}$ & $\eta_{\mathbf{A} 1}$ & $\eta_{\mathbf{A} 2}$ & $\mathbf{S F}_{\mathbf{H D}}$ & $\mathbf{S F}_{\mathbf{D D}}$ & $\mathbf{S F}$ & $\begin{array}{c}\text { Boiler heat } \\
\text { cost } \\
(€ / \mathrm{kWh})\end{array}$ & $\begin{array}{c}\text { Solar heat } \\
\text { cost } \\
(€ / \mathrm{kWh})\end{array}$ & $\begin{array}{c}\text { Total heat } \\
\text { cost } \\
(€ / \mathrm{kWh})\end{array}$ \\
\hline 100 & 49.0 & 84.9 & 96.9 & 68.6 & 80.6 & 70.7 & 0.0568 & 0.2319 & 0.1806 \\
\hline 250 & 48.6 & 88.5 & 97.7 & 70.9 & 80.9 & 72.6 & 0.0548 & 0.1685 & 0.1374 \\
\hline 500 & 48.1 & 90.6 & 98.2 & 71.6 & 81.8 & 73.3 & 0.0534 & 0.1348 & 0.1131 \\
\hline 750 & 47.7 & 91.7 & 98.4 & 71.6 & 82.4 & 73.5 & 0.0527 & 0.1191 & 0.1015 \\
\hline 1000 & 47.3 & 92.4 & 98.6 & 71.3 & 83.1 & 73.3 & 0.0521 & 0.1097 & 0.0943 \\
\hline
\end{tabular}

\section{Geographical influence}

A third analysis has been conducted studying the behaviour of the system in different Spanish cities with a significant heat demand (higher than $25 \mathrm{kWh} / \mathrm{m}^{2}$ ). The cities have been selected considering a significant variety of heating demand and solar radiation. For each city the appropriate V/A ratio, in which the seasonal storage would be fully charged of thermal energy in the beginning of the heating period, has been selected. The obtained results are shown in Table 6. Note that applying this criterion the total cost per $\mathrm{kWh}$ remains almost constant although the solar fraction is significantly different.

Table 6. Technical and economic data for various cities in Spain $(\mathrm{A} / \mathrm{GD}=0.95)$

\begin{tabular}{|c|c|c|c|c|c|c|c|c|c|}
\hline City & $\mathrm{GSR}^{\mathrm{S}}$ & $\begin{array}{l}\text { V/A } \\
(\mathrm{m}) \\
\end{array}$ & $\mathrm{HD}^{\&}$ & $\begin{array}{r}\mathbf{S F}_{\mathrm{HD}} \\
(\%) \\
\end{array}$ & $\mathrm{DD}^{\&}$ & $\begin{array}{c}\mathbf{S F}_{\mathbf{D D}} \\
(\%) \\
\end{array}$ & $\begin{array}{c}\text { Boiler heat } \\
\text { cost } \\
(€ / \mathrm{kWh})\end{array}$ & $\begin{array}{c}\text { Solar heat } \\
\text { cost } \\
(€ / \mathrm{kWh}) \\
\end{array}$ & $\begin{array}{c}\text { Total heat } \\
\text { cost } \\
(€ / \mathrm{kWh})\end{array}$ \\
\hline Oviedo & 1105 & 2.6 & 48.3 & 41.9 & 13.3 & 77.8 & 0.0479 & 0.1598 & 0.1011 \\
\hline Vitoria & 1146 & 4.0 & 65.4 & 49.4 & 13.5 & 81.9 & 0.0502 & 0.1482 & 0.1025 \\
\hline La Coruña & 1166 & 3.8 & 30.0 & 52.6 & 13.0 & 72.2 & 0.0512 & 0.1660 & 0.1166 \\
\hline Barcelona & 1369 & 4.8 & 28.3 & 74.1 & 12.8 & 79.9 & 0.0546 & 0.1372 & 0.1168 \\
\hline Burgos & 1379 & 5.0 & 77.1 & 56.7 & 13.8 & 82.6 & 0.0505 & 0.1360 & 0.1014 \\
\hline Soria & 1470 & 5.5 & 72.1 & 62.1 & 13.7 & 87.2 & 0.0512 & 0.1308 & 0.1029 \\
\hline Salamanca & 1501 & 6.2 & 62.3 & 73.7 & 13.5 & 88.6 & 0.0533 & 0.1215 & 0.1049 \\
\hline Avila & 1531 & 5.9 & 69.5 & 71.8 & 13.7 & 88.7 & 0.0527 & 0.1196 & 0.1020 \\
\hline Zaragoza & 1582 & 5.5 & 40.6 & 71.6 & 12.9 & 81.8 & 0.0534 & 0.1348 & 0.1131 \\
\hline Jaen & 1612 & 6.7 & 26.2 & 90.9 & 12.3 & 82.4 & 0.0644 & 0.1331 & 0.1255 \\
\hline Granada & 1673 & 6.8 & 37.4 & 87.3 & 12.9 & 87.4 & 0.0611 & 0.1243 & 0.1163 \\
\hline
\end{tabular}

\$ GSR [17]: Annual Global Horizontal Solar Radiation $\left(\mathrm{kWh} / \mathrm{m}^{2}\right)$

${ }^{\&}$ HD [18]: Annual Heating Demand (kWh/m²), DD [18]: Annual DHW Demand $\left(\mathrm{kWh} / \mathrm{m}^{2}\right)$ 


\section{Conclusion}

This work is intended to be a design guide to promote the installation of solar systems with seasonal storage in different climatic areas in Spain. These systems are able of covering heating and DHW demands with high solar fractions. Technical design parameters and economical data are provided for a CSHPSS system coping with the demand from a district of 500 dwellings located in Zaragoza with a solar fraction of $73 \%$. The unit cost of solar heat ( $135 € / \mathrm{MWh})$ is 2.5 times the cost of the boiler heat (53€/MWh). The obtained results are compared favourably with similar experiences available in Europe. Energy policy should incorporate the development of CSHPSS systems in the medium term strategies. The high initial investment cost can be reduced with an advanced planning which would allow big solar plants to be built together with the buildings districts they will serve.

\section{Acknowledgments}

This work was developed within the framework of research project ENE2007-67122, funded by the Spanish Government (Energy program) and the European Union (FEDER program).

\section{References}

[1] Real Decreto 314/2006: Código Técnico de la Edificación. BOE, 28 de marzo de 2006.

[2] A. Heller. 15 years of R\&D in central solar heating in Denmark. Solar Energy, Vol. 69, pp. 437-447, 2000.

[3] T. Schmidt, D. Mangold, H. Muller. Central solar heating plants with seasonal storage in Germany. Solar Energy, Vol. 76, pp. 165-174, 2004.

[4] K. Ellehauge, T.E. Pedersen. Solar heat storages in district heating networks. Energienet.dk, PREHEAT project no. 2006-2-6750, July 2007.

[5] T. Schmidt, D. Mangold. Status of solar thermal seasonal storage in Germany. Effstock, 2009.

[6] TRNSYS 16: a TRansient SYstem Simulation program. SEL, University of Wisconsin-Madison, 2004.

[7] M.A. Lozano, J.C. Ramos, L.M. Serra. Cost optimization of the design of CHCP (combined heat, cooling and power) systems under legal constraints. Energy, Vol. 35, pp. 794-805, 2010.

[8] EnergyPlus Weather Data (http://apps1.eere.energy.gov/buildings/energyplus/cfm/weather_data.cfm).

[9] AENOR. Norma UNE 94002: Instalaciones solares térmicas para producción de agua caliente sanitaria.

[10] EuroStat. Energy Data (http://epp.eurostat.ec.europa.eu/portal/page/portal/energy/data/database).

[11] Thermital. Tarifa de precios: España 09/2008.

[12] Sedical. Programas de cálculo y Tarifa Profesional 2007.

[13] E. Fabrizio et al. An hourly modelling framework for the assessment of energy sources exploitation and energy converters selection and sizing in buildings. Energy and Buildings, Vol. 41, pp.1037-1050, 2009.

[14] S.M. Walas. Chemical Process Equipment. Butterworth-Heinemann, 1960.

[15] G.D. Ulrich, P.T. Vasudevan. Chemical Engineering Process Design and Economics. Process Publ., 2004.

[16] S. Raab, D. Mangold, W. Heidemann, H. Muller. Simulation on solar assisted district heating systems with solar fractions of 35\%. ISES Solar World Congress, 2003.

[17] IDAE. Pliego de condiciones técnicas de instalaciones de baja temperatura, 2009.

[18] IDAE. Escala de Calificación Energética para Edificios de Nueva Construcción, 2009. 